\title{
Chemical cues mediating aphid location by natural enemies
}

\author{
EduARDo HATANO ${ }^{1,2}$, Grit KUNERT ${ }^{2}$, J.P. MICHAUD ${ }^{3}$ and WoLfGANG W. WEISSER ${ }^{1}$ \\ ${ }^{1}$ Institute of Ecology, Friedrich-Schiller-University Jena, Dornburger Str. 159, 07745 Jena, Germany; \\ e-mails: ehatano@ice.mpg.de,wolfgang.weisser@uni-jena.de \\ ${ }^{2}$ Max-Planck-Institute for Chemical Ecology, Hans-Knöll-Str. 8, 07745 Jena, Germany; e-mail: gkunert@ice.mpg.de \\ ${ }^{3}$ Kansas State University, Agricultural Research Center-Hays, 1232 240th Ave., Hays, KS 67601, USA; e-mail: jpmi@ksu.edu
}

Key words. Aphid, natural enemies, host selection, semiochemicals, infochemical

\begin{abstract}
There is increasing evidence that chemical cues play a pivotal role in host selection by the natural enemies of aphids. We use Vinson's (1976) division of the host selection process into habitat location, host location and host acceptance for both parasitoids and predators and review what is known about the role of semiochemicals in aphid selection by natural enemies. For habitat location (i.e. detection of the host plant), volatiles emitted by plants after aphid attack have been described for a number of plant-aphid interactions. These synomones indicate not only the presence of an aphid host plant to the predator or parasitoid, but also the presence of aphids. Volatiles emitted from undamaged host plants are often attractive to aphid parasitoids, but less so for predators. Host location by the natural enemy on the food plant is guided by semiochemicals that mostly originate from the aphids, in particular aphid alarm pheromone, honeydew, or the smell of the aphid itself. Host acceptance is guided by contact chemicals for both predators and parasitoids. In parasitoids, host recognition may be based on visual cues or on contact chemicals on the aphid's cuticle, whereas host acceptance is ultimately based on as yet unknown substances within the aphid's hemolymph. While it appears that many predators and parasitoids are attracted to the same semiochemicals, synergistic and antagonistic interactions among chemical substances have only rarely been investigated. More research into model systems is needed, not only to identify important semiochemicals, but also to determine their range of attraction. Recent progress in the development of analytical techniques has created new opportunities to improve our understanding of the chemical ecology of aphid-natural enemy interactions in the coming years.
\end{abstract}

\section{INTRODUCTION}

Prey location in a complex environment, filled with different plants and animal species, is a complex task. Predatory and parasitic insects have specialized sensory nervous systems that allow them to use a variety of cues to find and identify target organisms. Cues can be physical such as colour, sound, shape and size as well as chemical and these may be useful for long or short range attraction to prey. In this paper, we focus on the chemical cues used by aphid predators and parasitoids to detect their aphid (Hemiptera: Aphididae) prey or host. In recent years, much insight has been gained into the chemical ecology of aphid-natural enemy interactions and the large number of articles describing new findings suggests that a review on the current state of our knowledge would be useful. Reviewing physical cues is beyond the scope of the current paper, although we refer to these cues wherever appropriate.

For parasitoids, Vinson (1976) divided the host selection process into three different steps. The first step is habitat location and the second is host location. We define habitat location as finding the host plant of an aphid species and host location as locating the aphid when the natural enemy is already on the plant. Thus, in our terminology, habitat location is analogous to food plant location. Habitat location may also be defined as finding the habitat of the host plant, e.g. a meadow. However, we believe that for aphid natural enemies the distinction between finding a plant and finding an aphid on the plant is more useful, even though it is likely that for some natural enemies the search for hosts may start before landing on the plant. Because aphids only occupy a fraction of all host plants available, first finding a plant and then searching for aphids may not be a very efficient strategy. For this reason, many aphid natural enemies do not search for a "host habitat" but for a "habitat with hosts".

In Vinson's (1976) terminology, the final step in the host selection process is host acceptance, which is the proper act of oviposition or host/prey consumption (cf. Steidle \& van Loon, 2002). For parasitoids, this final step has been divided into host recognition and host acceptance (Michaud \& Mackauer, 1994; Muratori et al., 2006). A host may be recognized visually, or by antennal contact with chemical cues in the aphid cuticle. Final host acceptance depends on an assessment of host quality made during ovipositor probing, but a host may be rejected either after recognition or after ovipositor probing.

Although Vinson (1976) developed his framework to characterize the parasitoid search process, it can also be used for aphid predators. Whereas in aphid parasitoids the host is primarily used for oviposition, it may also be used for host feeding, or as a source of honeydew. Aphid predators need to find aphids for both feeding and oviposition, unless they obtain food from non-aphid prey or plant sources. In general, host/prey selection by both 
aphid predators and parasitoids is a step-wise process consistent with Vinson's framework.

We start with a brief discussion of the particular challenges involved in the use of chemical cues for host selection and then review what is known about the importance of chemical cues in each step of the host selection process. We will not review the signal cascades within the organisms (plants, aphids or natural enemies) that are involved in the production and detection of chemical cues. The responses of plants to feeding by aphids and other insect herbivores and the activation of signalling pathways have been recently reviewed (Walling, 2000; de Vos et al., 2007; Kempema et al., 2007).

\section{THE DETECTABILITY-RELIABILITY PROBLEM AND THE SEARCH FOR CHEMICAL CUES}

In an ecological context, semiochemicals are chemical substances that convey information between two organisms, evoking a behavioural or physiological response that is adaptive to one of the organisms or both (Vet \& Dicke, 1992). Semiochemicals are classified, not with respect to their chemical properties or source, but rather according to their ecological roles (Nordlund \& Lewis, 1976; Dicke \& Sabelis, 1988; Vet \& Dicke, 1992). While pheromones are semiochemicals released by one individual and perceived by another of the same species, allelochemicals are perceived by individuals of a different species. Allelochemicals can be further subdivided into different categories depending on the beneficiary of the signal. If the only beneficiary is the perceiver, the allelochemical is termed an allomone; if only the fitness of the producer is increased, it is termed a kairomone, and if both producer and perceiver benefit from the information exchange it is termed a synomone. The classification of a chemical compound may thus change according to the studied interaction. Pheromones of herbivores, for example, that may be perceived by a natural enemy and used to locate it are, for this interaction, classified as kairomones (Gabrys et al., 1997; Glinwood et al., 1999; Al Abassi et al., 2000).

On searching for herbivores, natural enemies face the dilemma of reliability versus detectability (Vet \& Dicke, 1992). Volatiles produced directly by herbivores give reliable information about their presence, but occur in low concentrations in the environment due to the low biomass of aphids. Plant volatiles, on the other hand, are easily detected because of their high biomass, but are less reliable since plants may or may not harbor herbivores. Vet \& Dicke (1992) suggested that, in general, natural enemies might use the following strategies to overcome the reliability-detectability problem: (1) use more conspicuous semiochemicals from herbivore stages other than the one susceptible to attack, (2) focus responses on stimuli created by specific interactions between the herbivore and its plant, or (3) learn to link easy-to-detect stimuli to reliable but hard-to-detect stimuli. The first possibility is not useful for aphid natural enemies as aphid stages have such low biomass, but the other two are frequently used.

\section{SEMIOCHEMICALS INVOLVED IN THE HOST SELECTION PROCESS}

\section{Habitat location}

Aphid natural enemies must first locate aphid habitat, i.e. a host plant where aphids might be present. Attraction to (undamaged) host plants has been shown for a number of aphid parasitoids (Hymenoptera: Braconidae), e.g. Diaretiella rapae (M'Intosh) (Read et al., 1970), Lysiphlebus testaceipes (Cresson) (Schuster \& Starks, 1974), Trioxys indicus Subba Rao and Sharma (Singh \& Sinha, 1982), Aphidius uzbekistanicus Luzhetski, Aphidius ervi Haliday (Powell \& Zhang, 1983), Aphidius rhopalosiphi De Stephani-Perez, Lysiphlebus fabarum (Marshall), Praon sp. (Van Emden, 1988), and Aphidius funebris Mackauer (Pareja et al., 2007) so that at first sight it appears to be a general phenomenon in aphid parasitoids. However, the parasitoid Aphidius nigripes Ashmead is not attracted to the odour of potato plants, the host plant of the aphid Macrosiphum euphorbiae (Thomas) (Bouchard \& Cloutier, 1985). The aphids M. euphorbiae and Myzus persicae (Sulzer) are the most common hosts of $A$. nigripes, but are very polyphagous species. Thus, it is possible that generalist parasitoids, or those that attack aphids with a wide host range, are less likely to respond to cues from plants without any additional evidence that aphids are present. However, A. ervi is also quite polyphagous, but is attracted by uninfested plants of its aphid hosts (Powell \& Zhang, 1983), suggesting more study is needed before generalisations can be drawn.

In contrast to parasitoids, aphid predators mostly appear not to use odours of undamaged plants to locate aphids. While ladybirds and other aphid natural enemies frequently visit plants for purposes such as nectar or pollen feeding, and may be attracted to these plants in the absence of aphids (e.g. Michaud \& Qureshi, 2005), laboratory studies have often failed to show attraction to undamaged plants. For example, the ladybird (Coleoptera: Coccinellidae) species Coccinella septempunctata L. (Ninkovic et al., 2001) and Adalia bipunctata (L.) (Francis et al., 2004), and the hoverfly Episyrphus balteatus (DeGeer) (Diptera: Syrphidae) (Francis et al., 2005b) were not attracted to odours from their (undamaged) host plant. An exception is Chrysoperla carnea (Stephens) (Neuroptera: Chrysopidae) that is attracted to plant volatiles (Hagen et al., 1976). The number of predator species tested is still low, but it appears that aphid predators, which are usually more polyphagous than parasitoids, are generally not attracted by the odour of undamaged plants without evidence of aphids. There is need for more testing, in particular for those species that not only feed on aphids but also feed on plant pollen, nectar and other plant parts.

The first evidence that plants can modify their volatile emissions in response to aphid attack was given by Guerrieri et al. (1993) who found that the parasitoid A. ervi was attracted to plants damaged by aphids, but not to undamaged plants. In fact, early evidence that damaged plants emit allelochemicals only after herbivory was given by Read et al. (1970) who showed attraction of 
TABLE 1. List of chemical compounds from different aphid-plant complexes and their effect on natural enemies responses .

\begin{tabular}{|c|c|c|c|c|c|}
\hline HABITAT LOCATION & Plant & Aphid & Natural enemy & Effect & Reference \\
\hline \multirow{4}{*}{$\begin{array}{l}\text { 6-methyl-5-hepten-2-one } \\
\text { (MHO) }\end{array}$} & V. faba & A. pisum & A. ervi & Attract & Du et al., 1998; Powell et al., 1998 \\
\hline & C. nigra & U. jacea & A. funebris & Attract & Pareja et al., 2007 \\
\hline & C. nigra & U. jacea & A. uzbekistanicus & Repel & Holler et al., 1994 \\
\hline & T. avestivum & R. padi & A. rhopalosiphi & None & Gonzales et al., 1999 \\
\hline (Z)-3-hexenyl acetate & C. nigra & U. jacea & A. funebris & Attract & Pareja et al., 2007 \\
\hline Allyl isothiocyanate & B. oleracea & B. brassicae & D. rapae & Attract & Read et al., 1970 \\
\hline Methyl salicylate & G. $\max$ & A. glycines & $\begin{array}{l}\text { C. septempunctata } \\
\text { Syrphid flies }\end{array}$ & $\begin{array}{l}\text { Attract } \\
\text { Attract }\end{array}$ & Zhu \& Park, 2005 \\
\hline (Z)-jasmone & & & $\begin{array}{l}\text { A. ervi } \\
\text { C. septempunctata }\end{array}$ & $\begin{array}{l}\text { Attract } \\
\text { Attract }\end{array}$ & Birkett et al., 2000 \\
\hline Benzaldehyde & C. sinensis & T. aurantii & $\begin{array}{l}\text { C. sinica } \\
\text { C. septempunctata }\end{array}$ & $\begin{array}{l}\text { Attract } \\
\text { Attract }\end{array}$ & Han \& Chen, 2002a, b \\
\hline \multicolumn{6}{|l|}{ HOST LOCATION } \\
\hline Indole acetaldehyde & Lucerne & & $\begin{array}{l}\text { Hippodamia spp. } \\
\text { C. carnea }\end{array}$ & $\begin{array}{l}\text { Attract } \\
\text { Attract }\end{array}$ & van Emden \& Hagen, 1976 \\
\hline \multirow{8}{*}{$(E)-\beta$-farnesene } & & M. persicae & $\begin{array}{l}\text { H. convergens } \\
\text { C. septempunctata }\end{array}$ & $\begin{array}{l}\text { Attract } \\
\text { Attract }\end{array}$ & $\begin{array}{l}\text { Acar et al., } 2001 \\
\text { Al Abassi et al., } 2000\end{array}$ \\
\hline & & $\begin{array}{l}\text { M. persicae } \\
\text { A. pisum }\end{array}$ & A. bipunctata & Attract & Francis et al., 2004 \\
\hline & & $\begin{array}{l}\text { M. viciae } \\
\text { A. pisum } \\
\text { A. fabae }\end{array}$ & E. balteatus & Attract & Francis et al., 2005b \\
\hline & & & $\begin{array}{l}\text { P. melanarius } \\
\text { H. rufipes }\end{array}$ & $\begin{array}{l}\text { Attract } \\
\text { Attract }\end{array}$ & Kielty et al., 1996 \\
\hline & & & N. brevicollis & None & Kielty et al., 1996 \\
\hline & & S. avenae & $\begin{array}{l}\text { A. uzbekistanicus } \\
\text { P. volucre }\end{array}$ & $\begin{array}{l}\text { Attract } \\
\text { Attract }\end{array}$ & Micha \& Wyss, 1996 \\
\hline & & S. avenae & L. testaceipes & None & Micha \& Wyss, 1996 \\
\hline & & & C. cognata & None & Boo et al., 1998 \\
\hline \multicolumn{6}{|l|}{ HABITAT AND HOST LOCATION } \\
\hline \multirow[b]{2}{*}{$(4 \mathrm{a} S, 7 S, 7 \mathrm{a} R)$-nepetalactone } & & & C. cognata & Attract & Boo et al., 1998 \\
\hline & & & $\begin{array}{l}\text { A. ervi } \\
\text { A. eadyi }\end{array}$ & $\begin{array}{l}\text { Attract } \\
\text { Attract }\end{array}$ & Glinwood et al., 1999 \\
\hline \multirow{3}{*}{$(1 R, 4 \mathrm{a} S, 7 S, 7 \mathrm{a} R)$-nepetalactol } & & & C. oculata & Attract & Zhu et al., 2005 \\
\hline & & & P. volucre & Attract & Gabrys et al., 1997 \\
\hline & & & D. rapae & Attract & \\
\hline \multicolumn{6}{|l|}{ HOST ACCEPTANCE } \\
\hline \multirow{4}{*}{$\begin{array}{l}\text { long hydrocarbon chains, wax } \\
\text { esters, alcohols, and aldehydes }\end{array}$} & & S. avenae & A. rhopalosiphi & Accept & Muratori et al., 2006 \\
\hline & & P. tessellatus & F. tarquinius & Accept & Lohman et al., 2006 \\
\hline & & P. tessellatus & C. slossonae & Accept & Lohman et al., 2006 \\
\hline & & P. tessellatus & S. ribesii & Accept & Lohman et al., 2006 \\
\hline
\end{tabular}

Diaretiella rapae (M'Intosh) (Hymenoptera: Braconidae) to mustard oil, allyl isothiocyanate (Table 1), emitted by collard, Brassica oleracea, in response to damage by the aphid, Brevicoryne brassicae (L.) (Read et al., 1970). Thereafter, a number of studies reported attraction of both aphid parasitoids and predators to the "plant-aphid complex" (also "plant-host complex"). Because this term refers to a set-up where a natural enemy can choose between a plant where aphids have been feeding and a control, or clean plant, it is often not clear whether attraction is due to volatiles emitted by the plant, the aphid, or aphid residues on the plant. Guerrieri et al. (1993) tested plants where remains of aphids had been removed to show that the plant changed its volatile profile. A number of subsequent studies supported this result ( $\mathrm{Du}$ et al., 1996, 1998; Guerrieri et al., 1999). For example, Du et al. (1996) used a no-choice wind-tunnel experiment to demonstrate that a higher percentage of naïve female parasitoids landed on broad beans, Vicia faba L., damaged by Acyrthosiphon pisum (Harris) than on undamaged plants or aphids alone. These experiments suggested that not only herbivore-induced plant volatiles can attract aphid parasitoids, but also that volatiles from exuviae and faeces do not influence parasitoid behaviour at long range, possibly because of their low detectability. It was clear from the results that the main stimuli attractive to parasitoids were released from the damaged plant and that 
plants produce semiochemicals in concentrations sufficient to be detected by parasitoids.

Attraction to aphid-damaged plants has also been shown for predators such as $C$. septempunctata and $C$. sinica (Han \& Chen, 2002a). Ninkovic et al. (2001) reported that $C$. septempunctata was attracted to odours from barley plants (Hordeum volgare) infested or previously infested by the aphid, Rhopalosiphum padi in a four-arm olfactometer assay, but not to volatiles from uninfested plants or undisturbed aphids. For both parasitoids and predators there is now increasing evidence for a role of plant-derived synomones in natural enemy habitat location.

The first study to identify aphid-induced volatiles was by $\mathrm{Du}$ et al. (1998), who tested the electroantennogram responses of $A$. ervi females to volatile compounds from broad bean, $V$. faba. Among the volatiles produced by the plant in response to aphid attack, 6-methyl-5-hepten2-one (MHO) was identified to be mainly responsible for attraction of the parasitoid. A number of other compounds also elicited responses in an olfactometer, but only MHO elicited a parasitoid flight response (Powell et al., 1998). Since the seminal study by Du et al. (1998), a number of other model systems have demonstrated a special role for MHO (Table 1). It was even suggested that MHO acts as an elicitor of dispersal for the parasitoid $A$. uzbekistanicus, to avoid attack by the hyperparasitioid Alloxysta victrix (Westwood) (Hymenoptera: Alloxystidae), as MHO was detected in the headspace of the hyperparasitoid (Höller et al., 1994). MHO is, however, not attractive to all parasitoids. For example, MHO was detected among the entrained volatiles of wheat plants damaged by $R$. padi, but was not attractive to the parasitoid A. rhopalosiphi when offered alone (Gonzales et al., 1999). Interestingly, whereas MHO is induced in $V$. faba infested with $A$. pisum ostensibly to attract $A$. ervi females, $V$. faba infested with Aphis fabae Scopoli (Hymenoptera: Aphididae) does not produce this volatile chemical and attracts significantly fewer $A$. ervi females for which A. fabae is not a host (Du et al., 1996, 1998; Powell et al., 1998; Guerrieri et al., 1999). Clearly, the role of MHO needs to be investigated in more detail. Other compounds emitted from aphid-damaged plants that attract certain parasitoids are (Z)-3-hexenyl acetate and (Z)-jasmone (Table 1).

MHO appears to play no role in habitat location by aphid predators and other induced compounds have been implicated in guiding predator searching behaviour. Zhu \& Park (2005) examined the volatile emissions of soybean plants, Glycine max L. and identified methyl salicylate (Table 1) as a compound induced by feeding of the aphid Aphis glycines Matsumura. When methyl salicylate was applied to the antennae of $C$. septempunctata, it elicited a positive EAG response and also attracted this predator and syrphid flies to traps (Zhu \& Park, 2005). $(Z)$-jasmone (Table 1 ) is a volatile compound of plants known for activating plant defenses and will attract the predator C. septempunctata in a four-arm olfactometer and the parasitoid $A$. ervi in a wind tunnel (Birkett et al.,
2000). Interestingly, $(Z)$-jasmone induced the emission of (E)- $\beta$-ocimene in $V$. faba, which also attracted the parasitoid (Birkett et al., 2000). Han \& Chen (2002a, b) detected high amounts of benzaldehyde released from tea shoots, Camellia sinensis L., when damaged by Toxoptera aurantii (Boyer de Fonscolombe), which is probably formed from a cyanogenic glycoside hydrolyzed by salivary enzymes of the aphid (Table 1). Benzaldehyde elicited positive EAG responses and was attractive to Aphidius sp. parasitoids and the predators Chrysopa sinica Tjeder (Neuroptera: Chrysopidae) and C. septempunctata (Han \& Chen 2002a, b). As in the case of parasitoids, the number of prey-predator systems investigated is increasing and it is likely that more compounds will be detected in the coming years.

One special case of habitat location semiochemicals are aphid sex pheromones. For many aphid species, sex pheromones were identified as a mixture of two monoterpenes, (+)-(4aS,7S,7aR)-nepetalactone and (-)-(1R,4aS,7S, $7 \mathrm{a} R$ )-nepetalactol (Table 1$)$, in ratios that vary according to the species (Pickett et al., 1992). These volatile compounds have been shown to attract female parasitoids in the field (Hardie et al., 1991, 1994) and elicit oriented flights by $A$. ervi and Aphidius eadyi Starý females when they are added to a piece of filter paper next to $V$. faba plants in the lab (Glinwood et al., 1999). Other examples of attraction to aphid sex pheromones include the parasitoids Praon volucre (Haliday) (Hymenoptera: Aphidiidae) and D. rapae (Gabrys et al., 1997), and the predators Chrysopa cognata McLachlan (Neuroptera: Chrysopidae) (Boo et al., 1998), and Chrysopa oculata Say (Neuroptera: Chrysopidae) (Zhu et al., 2005). Although sex pheromones reliably indicate the presence of aphids, they are only useful foraging cues in autumn when sexual morphs are produced.

To summarize, the seminal study by Du et al. (1996) started the search for aphid-induced volatiles important for their location by predators and parasitoids. While such compounds are important for habitat location in many systems, many parasitoids are also attracted to host plants free of aphids. Further work is needed to (i) test attraction of predators to undamaged plants, (ii) identify volatile compounds from aphid-infested plants and (iii) test the range of attraction of these volatiles under field conditions.

\section{Aphid location}

Following habitat location, natural enemies use short range chemical and physical cues to search for a suitable herbivore on the host plant. Among physical cues, visual stimuli (colour and shape) and aphid movement have been shown to be important factors for a number of aphid parasitoids (e.g. Michaud \& Mackauer, 1994, 1995) and predators (e.g. Harmon et al., 1998). For example, A. ervi prefers to oviposit into green rather than red clones of the aphid A. pisum (Michaud \& Mackauer, 1994; Libbrecht et al., 2007). Praon pequodorum Viereck females rarely attack aphids when they are not moving (Michaud \& Mackauer, 1995). The ladybirds (Coleoptera: Coccinellidae) C. septempunctata, Hippodamia convergens Guerin, 
Harmonia axyridis (Pallas), and Coleomegilla maculata (DeGeer) selectively attack red and green clones of $A$. pisum (Harmon et al., 1998). Therefore, predators and parasitoids use a number of physical cues to locate aphids at short range and these may influence preferences for ovipositing or feeding on a particular species or clone.

Among the chemical cues used by natural enemies for aphid location, aphid honeydew was the first to be investigated (e.g. Bombosch \& Volk, 1966). Initially considered to be an important kairomone for habitat location, studies with various parasitoids and predators have shown that it often acts as an arrestant, i.e. it increases the time that natural enemies search for aphids on plants. Often, the natural enemy needs physical contact with honeydew to change its behaviour (Dixon, 1959; Bombosch \& Volk, 1966; Carter \& Dixon, 1984; Budenberg, 1990; Budenberg \& Powell, 1992; Budenberg et al., 1992; Ide et al., 2007). Aphid honeydew also acts as an oviposition stimulus for syrphid flies (Budenberg \& Powell, 1992) and for the predatory gall midge, Aphidoletes aphidimyza (Rondani) (Diptera: Cecidomyiidae) (Choi et al., 2004). The spraying of artificial honeydew to increase numbers of Hippodamia spp. and C. carnea in lucerne fields in California is one well-known example of the use of kairomones in aphid control (Hagen et al., 1971). Predators respond positively to the odour of a breakdown product of tryptophane, probably indole acetaldehyde (Table 1, Van Emden \& Hagen, 1976) and remain in the treated area even when aphids are absent. The usefulness of artificial honeydew in improving biological control has been repeatedly tested, for example to manipulate the spatial distributions of ladybirds (Ben Saad \& Bishop, 1976; Evans \& Richards, 1997). Hagen (1986) suggested that $C$. carnea detects a synonome from the crop before responding to the kairomone, but this has not yet been identified. Attraction to honeydew has been shown for the parasitoid A. rhopalosiphi (Gardner \& Dixon, 1985; Hagvar \& Hofsvang, 1989; Budenberg, 1990; Budenberg et al., 1992), although the range of detectability remains unclear. Recently, Choi et al. (2004) captured honeydew volatiles and found that the gall midge $A$. aphidimyza was attracted to them, suggesting that these may attract natural enemies from some distance. Results with the syrphid $E$. balteatus also suggest some attractant role of honeydew volatiles as females landed more frequently on corn ears contaminated with honeydew from Metopolophium dirhodum (Walker) (Hemiptera: Aphididae) than on clean ears (Budenberg et al., 1992). However, the amount of volatiles released is probably small and unlikely to be effective as a long range attractant until plants become heavily infested.

In addition to aphid honeydew, the aphid alarm pheromone, $(E)-\beta$-farnesene (EBF, Table 1) can be an important kairomone in aphid location. It is commonly released in the cornicle secretions of many aphid species (Francis et al., 2005a) to alert surrounding aphids of the presence of natural enemies (Grasswitz \& Paine, 1992; Francis et al., 2004, 2005b; Kunert et al., 2005). However, EBF is a sesquiterpenoid which reacts quickly with ozone (Pinto et al., 2007). Single aphids have peak emissions of $<50 \mathrm{ng}$ (Schwartzberg et al., 2008) and usually only the attacked aphid emits, whereas undisturbed aphids in the vicinity do not (Hatano et al., 2008). Thus, concentrations of EBF may be undetectable at a distance from the plant, likely limiting its usefulness to short range attraction. EBF is attractive to a number of aphid natural enemies such as the parasitoids A. uzbekistanicus and $P$. volucre (Micha \& Wyss, 1996), the syrphid E. balteatus (Francis et al., 2005b), the ladybirds A. bipunctata (Francis et al., 2004), C. septempunctata (Al Abassi et al., 2000), Harmonia axyridis Pallas (Harmel et al., 2007) and H. convergens (Acar et al., 2001), and the ground beetles Pterostichus melanarius Illiger (Coleoptera: Carabidae) and Harpalus rufipes (DeGeer) (Coleoptera: Carabidae) (Kielty et al., 1996). Presumably as a consequence of EBF emission, disturbed or squashed individuals of A. pisum and M. persicae attracted significantly higher numbers of $A$. bipunctata than undisturbed aphids (Francis et al., 2004) and the same was observed for the parasitoid A. uzbekistanicus attacking Sitobion avenae (Fabricius) (Hemiptera: Aphididae) (Micha \& Wyss, 1996). Interestingly, ladybird larvae can perceive EBF from an aphid captured by a conspecific larvae, alerting it to the presence of prey (Hemptinne et al., 2000). However, some aphid natural enemies are not attracted to EBF, including the predatory lacewing, C. cognata, and the parasitoid L. testaceipes, (Micha \& Wyss, 1996; Boo et al., 1998). Francis et al. (2005a) analysed the volatiles emitted from squashed aphids and found 8 out of 23 species that emit other compounds in addition to EBF and two species that did not emit EBF. Thus, there are other volatiles emitted by aphids that are candidate compounds for host location.

It is important to point out that semiochemicals involved in host location do not necessarily lead the natural enemy directly to the aphid. Rather, substances indicating the presence of aphids may cue behaviours such as intensive local search which improve prey detection. For example, when perceiving aphid cues, or after capturing an aphid, ladybird larvae switch from an extensive search to an intensive, area-restricted search by increasing their frequency of turning and reducing their speed (Dixon, 1959, 2000).

To summarize, there is ample evidence for the involvement of chemical cues in host location but they remain poorly understood. The identity of the semiochemicals emitted by healthy or attacked aphids, or via honeydew, has not been established except for the aphid alarm pheromone, EBF, which appears to have broad activity. Detection distance appears to vary depending on the semiochemical and may also differ among species of predators and parasitoids.

\section{HOST RECOGNITION AND ACCEPTANCE}

Once an aphid is located, natural enemies have to recognize it as potential prey before they attack it. In addition, parasitoids use ovipositor probing to assess host quality before oviposition. For host recognition, chemical cues can be important, in particular contact kairomones 
from the surface of aphid's cuticle. Most contact kairomones are not volatiles. Weinbrenner \& Völkl (2002) showed that contact kairomones affect host recognition by the parasitoid $A$. ervi, since washed pea aphids were attacked less often than non-washed aphids. Shed exuviae of aphids often elicit oviposition responses by parasitoids e.g. A. ervi (Powell et al., 1998; Battaglia et al., 2000) and A. rhopalosiphi (Muratori et al., 2006).

Various isolation methods have been used to identify semiochemicals involved in host recognition. Han \& Chen (2002a) used hexane and ether rinses of T. aurantii cuticles to test attraction of the parasitoid Aphidius $s p$., and the predators, $C$. sinica and $C$. septempunctata. The hexane rinse was more attractive than the ether rinse, possibly because it contained benzaldehyde, but all cuticle rinses acted as short range cues or contact semiochemicals for all natural enemies tested. Chemical and physical characteristics of the exuviae of $S$. avenae were described by Muratori et al. (2006), who found a great variety of long hydrocarbon chains (C25 to C31), and a few wax esters, alcohols, and aldehydes (Table 1) in extractions. The extractions also elicited antennal contacts and attacks by $A$. rhopalosiphi, and heat treatment applied to destroy the structure of the epicuticular surface did not diminish responses, suggesting that wax structure per se does not determine host recognition. A similar role of hydrocarbons in aphid recognition was demonstrated for Feniseca tarquinius (Abbot) (Lepidoptera: Lycaenidae), Chrysopa slossonae Banks (Neuroptera: Chrysopidae), Syrphus ribesii (L.) (Diptera: Syrphidae), and for parasitoids of the genus Lysiphlebus, some of which chemically mimic the hydrocarbons of their prey to deceive aphid-tending ants (Völkl, 1992; Liepert \& Dettner, 1993; Lohman et al., 2006).

Chemical and physical compounds in cornicle secretions are active at very short range or in direct contact with an aphid, usually stimulating attacks by parasitoids. This response to cornicle secretion appears to be innate and host specific (Battaglia et al., 1995, 2000). The parasitoid L. testaceipes responded differently toward $R$. padi homogenates and cornicle wax compared to those of the non-host Aphis nerii Boyer de Fonscolombe (Hemiptera: Aphididae). However, when the non-host was covered with $R$. padi's cornicle wax, L. testaceipes increased its attack frequency (Grasswitz \& Paine, 1992). Cornicle secretion is only produced by aphids during attack (Goff $\&$ Nault, 1974) and can be an effective defensive weapon against predators and parasitoids. However, when the secretion is hardened it poses no threat to natural enemies and may serve as a kairomone for host recognition.

Parasitoids also perceive the internal chemistry of their hosts via receptors on the ovipositor. Thus, probing ("test stinging") of the host, although indicative of attack, is also an investigatory behaviour (Grasswitz \& Paine, 1992; Powell et al., 1998). Le Ralec \& Rabasse (1988) studied the ovipositors of Aphidiinae and described three pairs of valvulae, in which the third valvulae surround the other two. Mechano- and chemoreceptors are present on the first and/or second valvulae depending on the species
(Larocca et al., 2007). The internal cues within aphids that elicit oviposition remain unknown, but it is clear that not all probes result in oviposition. Thus ovipositor probing is the final stage of host selection and terminates with acceptance or rejection. In species that use no visual cues such as Ephedrus californicus (Michaud \& Mackauer, 1994), host acceptance is entirely a function of stimuli perceived during ovipositor probing.

Many aphid predators probably assess the quality of their prey using receptors on the maxillae only after attack and following contact with body fluids (Nakamuta, 1984; Nakamuta \& Saito, 1985). Dixon (1958) reported that larvae of $A$. decempunctata only reject the poisonous Hyalopterus pruni (Geoffroy) (Hemiptera: Aphididae) after piercing its cuticle. Moreover, the same predator also fed on $A$. fabae and M. viciae, but regurgitated and released them after two minutes (Dixon, 1958).

Predators also use host cues to decide whether to lay eggs at a given site. For example, aphid odours and cornicle secretions induce oviposition in C. septempunctata (Evans \& Dixon, 1986). However, residues left by predators in previous visits to plants, in particular "larval tracks" may deter ovipositions by adults of the same or other species. Initially this was shown for green lacewings, Chrysopa oculata Say (Neuroptera: Chrysopidae) (Růžička, 1994), and for ladybirds including C. septempunctata (Růžička, 1997). Subsequently, it has been shown for a number of other species such as $H$. axyridis (Yasuda et al., 2000), Cycloneda limbifer Casey, Ceratomegilla undecimnotata (Schneider) (Růžička, 2003), A. bipunctata (e.g. Fréchette et al., 2004) and H. convergens (Michaud \& Jyoti, 2007). Some predators such as the syrphid fly E. balteatus also react to the presence of conspecific eggs and their chemical residues (Scholz \& Poehling, 2000). These responses are presumed to be adaptive because they reduce the risks of cannibalism and competition for offspring (Dixon, 2000)

To summarize, host recognition and acceptance by parasitoids and predators involve contact chemicals perceived after the aphid has been contacted with the antennae, probed with the ovipositor, or tasted with the mouthparts. Compounds present in the aphid cuticle are likely to be more important than components of cornicle secretion for host recognition. Understanding of the chemicals influencing host acceptance is still rudimentary, partly because of the large number of substances potentially involved, and the difficulty of constructing workable bioassays.

\section{INTERACTION AMONG SEMIOCHEMICALS}

Above we provided examples where a blend of volatiles was more important for habitat or host location than single compounds, i.e. where additive or synergistic interactions among semiochemicals occurred. However, there is also the possibility of antagonistic interactions among semiochemicals. A well-known example is the interaction between the aphid alarm pheromone EBF and $\beta$-caryophyllene, a sesquiterpenoid compound found in many plant species. $\beta$-caryophyllene is an EBF-inhibitor, 
altering not only the behaviour of the aphids, but also that of predators (Dawson et al., 1984; Mostafavi et al., 1996; Zhu et al., 1999; Al Abassi et al., 2000). The ratio of EBF to $\beta$-caryophyllene is important here; a minimum ratio of $1: 1$ elicited a positive response by $C$. septempunctata in a Y-tube olfactometer, while a ratio of $1: 3$ did not significantly attract the predator. The importance of this ratio was also demonstrated for the aphid parasitoid D. rapae exposed to the odour of genetically modified Arabidopsis thaliana plants which produced increased amounts of EBF relative to $\beta$-caryophyllene (Beale et al., 2006).

A new hypothesis for the use of volatiles by insects foraging for their suitable prey was presented by Bruce et al. (2005). In addition to the use of combined compounds in specific ratios, insects appear to time the arrival of these different compounds on their chemical receptors. This could allow natural enemies to differentiate suitable targets from unsuitable ones if the latter emitted the same compounds but with different timing. However, this hypothesis has to be yet demonstrated for aphid natural enemies.

To summarize, both synergistic and antagonistic interactions among semiochemicals have been described and there are likely to be many more, given the fact that the same semiochemicals are involved in many aphid-natural enemy interactions. Testing combinations of semiochemicals for synergistic or antagonistic effect is laborious but would provide a fuller understanding of aphid chemical ecology.

\section{CONCLUSIONS AND FUTURE DIRECTIONS}

Plants produce volatile chemicals that are conspicuous to many insects including herbivores and their natural enemies. Chemicals from plants, although less reliable than chemicals from aphids, are important cues that elicit foraging behaviour in many aphid natural enemies, in particular more specialised parasitoids. Currently, there is increasing evidence that volatile blends from aphiddamaged plants play a pivotal role in habitat location by both parasitoids and predators, although only a few model systems have been investigated in detail. Plant changes are probably triggered by elicitors present in the aphid saliva (de Vos et al., 2007). Among the short range cues used by natural enemies are the pheromones of aphids (alarm and sex), and honeydew. For parasitoids, contact kairomones in the aphid cuticle, in particular waxes may be used for host recognition, whereas chemicals within the hemolymph are important for host acceptance. For predators, such compounds may act as a feeding stimulus.

In most cases, one or only a few semiochemicals of importance have been described for a particular system and these often differ among natural enemy species, suggesting that particular plant-aphid-complexes emit specific volatile chemicals. However, there are also examples of redundancy where the same compound is used by many natural enemies, e.g. MHO (Table 1). More studies are needed that submit a particular parasitoid species to different aphid-plant complexes to investigate whether natural enemy responses differ among complexes that produce similar volatile chemicals. Chemical analyses of these volatile blends are needed to investigate subtle differences. Finally, all species are embedded in a network of ecological interactions that shape the evolution of all traits. Understanding the evolution of the semiochemicals requires taking into account the interactions of aphids with plants, competitors, natural enemies and mutualists. For this, more field experiments are needed to unravel the true significance of semiochemicals under natural conditions.

ACKNOWLEDGEMENTS. We gratefully thank two reviewers for extensive helpful comments that have greatly improved previous versions of this manuscript. We thank the Max Planck Society $(\mathrm{EH})$ and the DFG (GK, WWW) for financial support.

\section{REFERENCES}

Acar E.B., Medina J.C., Lee M.L. \& Booth G.M. 2001: Olfactory behavior of convergent lady beetles (Coleoptera: Coccinellidae) to alarm pheromone of green peach aphid (Hemiptera: Aphididae). Can. Entomol. 133: 389-397.

Al Abassi S., Birkett M.A., Pettersson J., Pickett J.A., WadHams L.J. \& Woodcock C.M. 2000: Response of the sevenspot ladybird to an aphid alarm pheromone and an alarm pheromone inhibitor is mediated by paired olfactory cells. $J$. Chem. Ecol. 26: 1765-1771.

Battaglia D., Pennacchio F., Romano A. \& Tranfaglia A. 1995: The role of physical cues in the regulation of host recognition and acceptance behavior of Aphidius ervi Haliday (Hymenoptera, Braconidae). J. Insect Behav. 8: 739-750.

Battaglia D., Poppy G., Powell W., Romano A., Tranfaglia A. \& Pennacchio F. 2000: Physical and chemical cues influencing the oviposition behaviour of Aphidius ervi. Entomol. Exp. Appl. 94: 219-227.

Beale M.H., Birkett M.A., Bruce T.J.A., Chamberlain K., Field L.M., Huttly A.K., Martin J.L., Parker R., Phillips A.L., Pickett J.A., Prosser I.M., Shewry P.R., Smart L.E., Wadhams L.J., Woodcock C.M. \& Zhang Y.H. 2006: Aphid alarm pheromone produced by transgenic plants affects aphid and parasitoid behavior. PNAS 103: 10509-10513.

BEN SAAD A.A. \& Bishop G.W. 1976: Effect of artificial honeydews on insect communities in potato fields. Envir. Entomol. 5: $453-457$.

Birkett M.A., Campbell C.A.M., Chamberlain K., Guerrieri E., Hick A.J., Martin J.L., Matthes M., Napier J.A., Pettersson J., Pickett J.A., Poppy G.M., Pow E.M., Pye B.J., Smart L.E., Wadhams G.H., Wadhams L.J. \& Woodcock C.M. 2000: New roles for cis-jasmone as an insect semiochemical and in plant defense. PNAS 97: 9329-9334.

Bombosch S. \& Volk S.T. 1966: Selection of the oviposition site by Syrphus corollae F. In Hodek I. (ed.): The Ecology of Aphidophagous Insects. Academia Publishing House, Prague, pp. 117-119.

Boo K.S., Chung I.B., Han K.S., Pickett J.A. \& Wadhams L.J. 1998: Response of the lacewing Chrysopa cognata to pheromones of its aphid prey. J. Chem. Ecol. 24: 631-643.

BOUCHARD Y. \& Cloutier C. 1985: Role of olfaction in host finding by aphid parasitoid Aphidius nigripes (Hymenoptera, Aphidiidae). J. Chem. Ecol. 11: 801-808.

Bruce T.J.A., Wadhams L.J. \& Woodcock C.M. 2005: Insect host location: a volatile situation. Trends Plant Sci. 10: 269-274.

BudENBERG W.J. 1990: Honeydew as a contact pheromone for aphid parasitoids. Entomol. Exp. Appl. 55: 139-148. 
Budenberg W.J. \& Powell W. 1992: The role of honeydew as an ovipositional stimulant for two species of syrphids. Entomol. Exp. Appl. 64: 57-61.

Budenberg W.J., Powell W. \& Clark S.J. 1992: The influence of aphids and honeydew on the leaving rate of searching aphid parasitoids from wheat plants. Entomol. Exp. Appl. 63: 259-264.

Carter M.C. \& Dixon A.F.G. 1984: Honeydew - an arrestant stimulus for Coccinellids. Ecol. Entomol. 9: 383-387.

Choi M.Y., Roitberg B.D., Shani A., Raworth D.A. \& Lee G.H. 2004: Olfactory response by the aphidophagous gall midge, Aphidoletes aphidimyza to honeydew from green peach aphid, Myzus persicae. Entomol. Exp. Appl. 111: $37-45$.

Dawson G.W., Griffiths D.C., Pickett J.A., Smith M.C. \& Woodсоск C.M. 1984: Natural inhibition of the aphid alarm pheromone. Entomol. Exp. Appl. 36: 197-199.

DE Vos M., KiM J.H. \& JANDER G. 2007: Biochemistry and molecular biology of Arabidopsis-aphid interactions. BioEssays 29: $871-883$.

Dicke M. \& SABelis M.W. 1988: Infochemical terminology: Based on cost-benefit analysis rather than origin of compounds? Funct. Ecol. 2: 131-139.

Dixon A.F.G. 1958: The escape responses shown by certain aphids to the presence of the coccinellid Adalia decempunctata (L.). Trans. R. Entomol. Soc. Lond. 110: 319-334.

Dixon A.F.G. 1959: An experimental-study of the searching behavior of the predatory Coccinellid beetle Adalia decempunctata (I). J. Anim. Ecol. 28: 259-281.

Dixon A.F.G. 2000: Foraging behaviour. In Dixon A.F.G. (ed.): Insect Predator-Prey Dynamics: Ladybird Beetles and Biological Control. Cambridge University Press, Cambridge, pp. 82-129.

Du Y.J., Poppy G.M. \& Powell W. 1996: Relative importance of semiochemicals from first and second trophic levels in host foraging behavior of Aphidius ervi. J. Chem. Ecol. 22: $1591-1605$

Du Y.J., Poppy G.M., Powell W., Pickett J.A., Wadhams L.J. \& WoodCock C.M. 1998: Identification of semiochemicals released during aphid feeding that attract parasitoid Aphidius ervi. J. Chem. Ecol. 24: 1355-1368.

Evans E.W. \& Dixon A.F.G. 1986: Cues for oviposition by ladybird beetles (Coccinellidae) - Response to aphids. $J$. Anim. Ecol. 55: 1027-1034.

Evans E.W. \& RichaRDS D.R. 1997: Managing the dispersal of ladybird beetles (Col.: Coccinellidae): Use of artificial honeydew to manipulate spatial distributions. Entomophaga 42: 93-102.

Francis F., Lognay G. \& Haubruge E. 2004: Olfactory responses to aphid and host plant volatile releases: $(E)$-betafarnesene an effective kairomone for the predator Adalia bipunctata. J. Chem. Ecol. 30: 741-755.

Francis F., Vandermoten S., Verheggen F., Lognay G. \& HauBRUGE E. 2005a: Is the (E)-beta-farnesene only volatile terpenoid in aphids? J. Appl. Entomol. 129: 6-11.

Francis F.D., Martin T., Lognay G. \& Haubruge E. 2005b: Role of $(E)$-beta-farnesene in systematic aphid prey location by Episyrphus balteatus larvae (Diptera: Syrphidae). Eur. J. Entomol. 102: 431-436.

Fréchette B., Dixon A.F.G, Alauzet C. \& Hemptinne J.L. 2004: Age and experience influence patch assessment for oviposition by an insect predator. Ecol. Entomol. 29: 578-583.

Gabrys B.J., Gadomski H.J., Klukowski Z., Pickett J.A., Soвota G.T., Wadhams L.J. \& Woodcock C.M. 1997: Sex pheromone of cabbage aphid Brevicoryne brassicae: Identifi- cation and field trapping of male aphids and parasitoids. $J$. Chem. Ecol. 23: 1881-1890.

GARDNER S.M. \& DiXon A.F.G. 1985: Plant structure and the foraging success of Aphidius rhopalosiphi (Hymenoptera, Aphidiidae). Ecol. Entomol. 10: 171-179.

Glinwood R.T., Du Y.J. \& Powell W. 1999: Responses to aphid sex pheromones by the pea aphid parasitoids Aphidius ervi and Aphidius eadyi. Entomol. Exp. Appl. 92: 227-232.

Goff A.M. \& Nault L.R. 1974: Aphid cornicle secretions ineffective against attack by parasitoid wasps. Environ. Entomol. 3: $565-566$.

GonZales W.L., Fuentes-Contreras E. \& Niemeyer H.M. 1999: Semiochemicals associated to spacing behaviour of the bird cherry-oat aphid Rhopalosiphum padi L. (Hem., Aphididae) do not affect the olfactometric behaviour of the cereal aphid parasitoid Aphidius rhopalosiphi De Stephani-Perez (Hym., Braconidae). J. Appl. Entomol. 123: 413-415.

Grasswitz T.R. \& Paine T.D. 1992: Kairomonal effect of an aphid cornicle secretion on Lysiphlebus testaceipes (Cresson) (Hymenoptera, Aphidiidae). J. Insect Behav. 5: 447-457.

Guerrieri E., Pennacchio F. \& Tremblay E. 1993: Flight behavior of the aphid parasitoid Aphidius ervi (Hymenoptera, Braconidae) in response to plant and host volatiles. Eur. $J$. Entomol. 90: 415-421.

Guerrieri E., Poppy G.M., Powell W., Tremblay E. \& PennacCHIO F. 1999: Induction and systemic release of herbivoreinduced plant volatiles mediating in-flight orientation of Aphidius ervi. J. Chem. Ecol. 25: 1247-1261.

HAGEN K.S. 1986: Ecosystem analysis: plant cultivar (HPR), entomophagous species and food supplement. In Boethel D.J. \& Eikenberry R.D. (eds): Interactions of Plant Resistance and Parasitoid and Predators of Insects. Wiley, New York, pp. 151-197.

Hagen K.S., Greany P., Sawall E.F. \& Tassan R.L. 1976: Tryptophan in artificial honeydews as a source of an attractant for adult Chrysopa carnea (Neuroptera, Chrysopidae). Environ. Entomol. 5: 458-468.

Hagen J.S., Sawall E.F. JR. \& Tassan R.L. 1971: Use of food sprays to increase effectiveness of entomophagous insects. Proc. Tall Timbers Conference On Ecological Animal Control By Habitat Management. Feb. 26-28, 1970, Tallahassee, Florida, USA. Vol. 2. pp. 59-81.

Hagvar E.B. \& Hofsvang T. 1989: Effect of honeydew and hosts on plant colonization by the aphid parasitoid Ephedrus cerasicola. Entomophaga 34: 495-501.

HAN B.Y. \& Chen Z.M. 2002a: Behavioral and electrophysiological responses of natural enemies to synomones from tea shoots and kairomones from tea aphids, Toxoptera aurantii. $J$. Chem. Ecol. 28: 2203-2219.

HAN B.Y. \& CHEN Z.M. 2002b: Composition of the volatiles from intact and mechanically pierced tea aphid-tea shoot complexes and their attraction to natural enemies of the tea aphid. J. Agr. Food Chem. 50: 2571-2575.

Hardie J., Hick A.J., Holler C., Mann J., Merritt L., Nottingham S.F., Powell W., Wadhams L.J., Witthinrich J. \& Wright A.F. 1994: The responses of Praon spp parasitoids to aphid sex-pheromone components in the field. Entomol. Exp. Appl. 71: 95-99.

Hardie J., Nottingham S.F., Powell W. \& Wadhams L.J. 1991: Synthetic aphid sex pheromone lures female parasitoids. Entomol. Exp. Appl. 61: 97-99.

Harmel N., Almohamad R., Fauconnier M.L., Du Jardin P., Verheggen F., Marlier M., Haubruge E. \& Francis F. 2007: Role of terpenes from aphid-infested potato on searching and oviposition behavior of Episyrphus balteatus. Insect Sci. 14: 57-63. 
Harmon J.P., Losey J.E. \& Ives A.R. 1998: The role of vision and color in the close proximity foraging behavior of four coccinellid species. Oecologia 115: 287-292.

Hatano E., Kunert G., Bartram S., Boland W., Gershenzon J. \& WeIsSER W.W. 2008: Do aphid colonies amplify their emission of alarm pheromone? J. Chem. Ecol. 34: 1149-1152.

Hemptinne J.L., Gaudin M., Dixon A.F.G. \& Lognay G. 2000: Social feeding in ladybird beetles: adaptive significance and mechanism. Chemoecology 10: 149-152.

Holler C., Micha S.G., Schulz S., Francke W. \& Pickett J.A. 1994: Enemy-induced dispersal in a parasitic wasp. Experientia 50: $182-185$.

Ide T., Suzuki N. \& Katayama N. 2007: The use of honeydew in foraging for aphids by larvae of the ladybird beetle, Coccinella septempunctata L. (Coleoptera: Coccinellidae). Ecol. Entomol. 32: 455-460.

Kempema L.A., Cui X.P., Holzer F.M., \& Walling L.L. 2007: Arabidopsis transcriptome changes in response to phloemfeeding silverleaf whitefly nymphs. Similarities and distinctions in responses to aphids. Plant Physiol. 143: 849-865.

Kielty J.P., AllenWilliams L.J., Underwood N. \& Eastwood E.A. 1996: Behavioral responses of three species of ground beetle (Coleoptera: Carabidae) to olfactory cues associated with prey and habitat. J. Insect Behav. 9: 237-250.

Kunert G., Otto S., Rose U.S.R., Gershenzon J. \& Weisser W.W. 2005: Alarm pheromone mediates production of winged dispersal morphs in aphids. Ecol. Lett. 8: 596-603.

Larocca A., Fanti P., Romano V.A., Marsicovetere E., Isidoro N., Romani R., Ruschioni S., Pennacchio F. \& Battaglia D. 2007: Functional bases of host-acceptance behaviour in the aphid parasitoid Aphidius ervi. Physiol. Entomol. 32: 305-312.

Le RALEC A. \& RABASSE J.M. 1988: Structure, sensory receptors and operation of the ovipositor of three Aphidiidae. In Niemczyk E. \& Dixon A.F.G. (eds): Ecology and Efectiveness of Aphidophaga. SPB Academic Publishing, The Netherlands, pp. 83-88.

LibBrecht R., Gwynn D.M. \& Fellowes M.D.E. 2007: Aphidius ervi preferentially attacks the green morph of the pea aphid, Acyrthosiphon pisum. J. Insect Behav. 20: 25-32.

LiePert C. \& DetTNER K. 1993: Recognition of aphid parasitoids by honeydew-collecting ants - the role of cuticular lipids in a chemical mimicry system. J. Chem. Ecol. 19: 2143-2153.

Lohman D.J., Liao Q. \& Pierce N.E. 2006: Convergence of chemical mimicry in a guild of aphid predators. Ecol. Entomol. 31: 41-51.

Micha S.G. \& Wyss U. 1996: Aphid alarm pheromone (E)-ßfarnesene: a host finding kairomone for the aphid primary parasitoid Aphidius uzbekistanicus (Hymenoptera: Aphidiinae). Chemoecology 7: 132-139.

Michaud J.P. \& JyOTI J.L. 2007: Repellency of conspecific and heterospecific larval residues to Hippodamia convergens (Coleoptera: Coccinellidae) ovipositing on sorghum plants. Eur. J. Entomol. 104: 399-405.

Michaud J.P. \& Mackauer M. 1994: The use of visual cues in host evaluation by Aphidiid wasps. 1. Comparison between 3 Aphidius parasitoids of the pea aphid. Entomol. Exp. Appl. 70: $273-283$.

Michaud J.P. \& Mackauer M. 1995: The use of visual cues in host evaluation by Aphidiid wasps. 2. Comparison between Ephedrus californicus, Monoctonus paulensis, and Praon pequodorum. Entomol. Exp. Appl. 74: 267-275.

Michaud J.P. \& QURESHI J.A. 2005: Induction of reproductive diapause in Hippodamia convergens (Coleoptera: Coccinellidae) hinges on prey quality and availability. Eur. J. Entomol. 102: $483-487$.
Mostafavi R., Henning J.A., Gardea-Torresday J. \& Ray I.M. 1996: Variation in aphid alarm pheromone content among glandular and eglandular-haired Medicago accessions. J. Chem. Ecol. 22: 1629-1638.

Muratori F., Le Ralec A., Lognay G. \& Hance T. 2006: Epicuticular factors involved in host recognition for the aphid parasitoid Aphidius rhopalosiphi. J. Chem. Ecol. 32: 579-593.

NaKamuta K. 1984: Visual orientation of a ladybeetle, Coccinella septempunctata L. (Coleoptera, Coccinellidae), toward its prey. Appl. Entomol. Zool. 19: 82-86.

Nakamuta K. \& Saito T. 1985: Recognition of aphid prey by the lady beetle, Coccinella septempunctata bruckii Mulsant (Coleoptera, Coccinellidae). Appl. Entomol. Zool. 20: 479-483.

Ninkovic V., Al Abassi S. \& Pettersson J. 2001: The influence of aphid-induced plant volatiles on ladybird beetle searching behavior. Biol. Control 21: 191-195.

NoRdLund D.A. \& LEWIS W.J. 1976: Termilogy of chemical releasing stimuli in intraspecific and interspecific interactions. J. Chem. Ecol. 2: 211-220.

Pareja M., Moraes M.C.B., Clark S.J., Birkett M.A. \& Powell W. 2007: Response of the aphid parasitoid Aphidius funebris to volatiles from undamaged and aphid-infested Centaurea nigra. J. Chem. Ecol. 33: 695-710.

Pickett J.A., Wadhams L.J., Woodcock C.M. \& Hardie J. 1992: The chemical ecology of aphids. Annu. Rev. Entomol. 37: 67-90.

Pinto D.M., Blande J.D., Nykanen R., Dong W.X., Nerg A.M. \& Holopainen J.K. 2007: Ozone degrades common herbivoreinduced plant volatiles: Does this affect herbivore prey location by predators and parasitoids? J. Chem. Ecol. 33: 683-694.

Powell W. \& Zhang Z.L. 1983: The reactions of 2 cereal aphid parasitoids, Aphidius uzbekistanicus and Aphidius ervi to host aphids and their food-plants. Physiol. Entomol. 8: 439-443.

Powell W., Pennacchio F., Poppy G.M. \& Tremblay E. 1998: Strategies involved in the location of hosts by the parasitoid Aphidius ervi Haliday (Hymenoptera: Braconidae: Aphidiinae). Biol. Control 11: 104-112.

Read D.P., Feeny P.P. \& Root R.B. 1970: Habitat selection by the aphid parasite Diaretiella rapae (Hymenoptera: Braconidae) and hyperparasite Charips brassicae (Hymenoptera: Cynipidae). Can. Entomol. 102: 1567-1578.

RŮŽIČKA Z. 1994: Oviposition-deterring pheromone in Chrysopa oculata (Neuroptera: Chrysopidae). Eur. J. Entomol. 91: 361-370.

RƯŽIČCA Z. 1997: Recognition of oviposition-deterring allomones by aphidophagous predators (Neuroptera: Chrysopidae, Coleoptera: Coccinellidae). Eur. J. Entomol. 94: 431-434.

RŮŽıČKA Z. 2003: Perception of oviposition-deterring larval tracks in aphidophagous coccinellids Cycloneda limbifer and Ceratomegilla undecimnotata (Coleoptera: Coccinellidae). Eur. J. Entomol. 100: 345-350.

Scholz D. \& Poenling H.M. 2000: Oviposition site selection in Episyrphus balteatus. Entomol. Exp. Appl. 94: 149-158.

SChUSTER D.J. \& STARKS K.J. 1974: Response of Lysiphlebus testaceipes in an olfactometer to a host and a non-host insect and to plants. Environ. Entomol. 3: 1034-1035.

Schwartzberg E., Kunert G., Stephan C., David A., Roese U.S., Gershenzon J., Boland W. \& Weisser W.W. 2008: Real-time analysis of alarm pheromone emission by the pea aphid (Acyrthosiphon pisum). J. Chem. Ecol. 34: 76-81. 
Singh R. \& Sinha T.B. 1982: Bionomics of Trioxys (Binodoxys) indicus Subba Rao and Sharma, an aphidiid parasitoid of Aphis craccivora Koch. 13. Host selection by the parasitoid. J. Appl. Entomol. 93: 64-75.

STEIDLE J.L.M. \& VAN LoON J.J.A. 2002: Chemoecology of parasitoid and predator oviposition behaviour. In Hilker M. \& Meiners T. (eds): Chemoecology of Insect Eggs and Egg Deposition. Blackwell, Berlin, pp. 291-318.

VAN EMDEN H.F. 1988: The potential for managing indigenous natural enemies of aphids on field crops. Philos. Trans. $R$. Soc. (B) 318: 183-201.

VAN EMDEN H.F. \& Hagen K.S. 1976: Olfactory reactions of green lacewing, Chrysopa carnea, to tryptophan and certain breakdown products (Neuroptera-Chrysopidae). Environ. Entomol. 5: 469-473.

Vet L.E.M. \& Dicke M. 1992: Ecology of infochemical use by natural enemies in a tritrophic context. Annu. Rev. Entomol. 37: 141-172.

VInSON S.B. 1976: Host selection by insect parasitoids. Аnпu. Rev. Entomol. 21: 109-133.

VöLKL W. 1992: Aphids or their parasitoids: Who actually benefits from ant-attendance? J. Anim. Ecol. 61: 273-281.
WaLLing L.L. 2000: The myriad plant responses to herbivores. J. Plant Growth Regul. 19: 195-216.

WeinBrenner M. \& VolKL W. 2002: Oviposition behaviour of the aphid parasitoid, Aphidius ervi: Are wet aphids recognized as host? Entomol. Exp. Appl. 103: 51-59.

Yasuda H., TAKagi T. \& Kogi G. 2000: Effects of conspecific and heterospecific larval tracks on the oviposition behaviour of the predatory ladybird Harmonia axyridis (Coleoptera: Coccinellidae). Eur. J. Entomol. 97: 551-553.

Zhu J.W., Cosse A.A., Obrycki J.J., Boo K.S. \& Baker T.C. 1999: Olfactory reactions of the twelve-spotted lady beetle, Coleomegilla maculata and the green lacewing, Chrysoperla carnea to semiochemicals released from their prey and host plant: Electroantennogram and behavioral responses. $J$. Chem. Ecol. 25: 1163-1177.

Zhu J., Obrycki J.J., Ochieng S.A., Baker T.C., Pickett J.A. \& SMILEY D. 2005: Attraction of two lacewing species to volatiles produced by host plants and aphid prey. Naturwissenschaften 92: 277-281.

ZhU J.W. \& PARK K.C. 2005: Methyl salicylate, a soybean aphid-induced plant volatile attractive to the predator Coccinella septempunctata. J. Chem. Ecol. 31: 1733-1746.

Received September 29, 2007; revised and accepted September 24, 2008 